\title{
Efforts to Improve Thematic Learning Results through Problem Based Learning Model With Power Point Media For Class $2^{\text {nd }}$ Students
}

\section{Chorina Dwi Jayanti}

SD Negeri 2 Sered

chorinadwijayanti@gmail.com

\section{Article History}

accepted $14 / 11 / 2020$

\begin{abstract}
The problems of this research are: low student learning outcomes on the theme of clean and healthy grade 2 SD Negeri 2 Sered Madukara District. The purpose of this study was to determine the increase in learning outcomes after the application of the problem based learning model with power point media with the theme 4 Clean and healthy life for grade 2 students at SD Negeri 2 Sered in 2020/2021. This research was conducted through a classroom action research process which includes four stages, namely planning (planing), action (action), observation (observation), and reflection (reflection). The research subjects were 13 grade students at SD Negeri 2 Sered. Data collection tools used observation sheets, and test questions. The results showed that: The use of problem-based learning models with power point media was able to improve student learning outcomes in learning, as evidenced in the second cycle of students who completed 11 students or $85 \%$ with an average grade of 81 .
\end{abstract}

Keywords: Learning outcomes, problem based learning, power point media

\begin{abstract}
Abstrak
Permasalahan penelitian ini yaitu : rendahnya hasil belajar siswa pada tema bersih dan sehat siswa kelas 2 SD Negeri 2 Sered Kecamatan Madukara. Tujuan penelitian ini yaitu mengetahui peningkatan hasil belajar setelah penerapan model problem based learning dengan media power point tema 4 Hidup bersih dan sehat siswa kelas 2 di SD Negeri 2 Sered Tahun 2020/2021. Penelitian ini dilakukan melalui proses penelitian tindakan kelas yang meliputi empat tahapan yaitu perencanaan (planing), pelaksanaan (action), observasi (observation), dan refleksi (reflection). Subjek penelitian adalah siswa kelas 2 SD Negeri 2 Sered yang berjumlah 13 siswa. Alat pengumpulan data menggunakan lembar observasi, dan soal-soal tes. Hasil penelitian menunjukkan bahwa :Penggunaan model problem based learning dengan media power point mampu meningkatkan hasil belajar siswa dalam pembelajaran, terbukti pada siklus II siswa yang tuntas mencapai 11 siswa atau $85 \%$ dengan nilai rata-rata kelas 81 .
\end{abstract}

Kata kunci: Hasil belajar, problem based learning, media power point

Social, Humanities, and Education Studies (SHEs): Conference Series https://jurnal.uns.ac.id/shes

p-ISSN 2620-9284

e-ISSN 2620-9292 


\section{PENDAHULUAN}

Pendidikan merupakan pilar utama dalam pengembangan sumber daya manusia pada suatu bangsa. Pendidikan diharapkan mampu membentuk sumber daya manusia yang berkualitas dan mandiri, serta memberi dukungan dan perubahan untuk perkembangan masyarakat, bangsa, dan negara Indonesia. Sesuai dengan yang termuat dalam Undang-Undang Republik Indonesia No. 20 tahun 2003 pasal 1 ayat 1 tentang Sistem Pendidikan Nasional (SISDIKNAS) menyebutkan bahwa "Pendidikan adalah usaha sadar dan terencana untuk mewujudkan suasana belajar dan proses pembelajaran agar siswa secara aktif mengembangkan potensi dirinya untuk memiliki kekuatan spiritual keagamaan, pengendalian diri, kepribadian, kecerdasan, akhlak mulia, serta keterampilan yang diperlukan dirinya, masyarakat, bangsa dan negara".

Sebagai tonggak dasar dari lembaga pendidikan di Indonesia, satuan pendidikan SD/MI juga tidak terbebas dari berbagai masalah, baik itu mengenai hasil belajar siswanya maupun kualitas mutu pendidikannya. Pendidik merupakan sosok yang memiliki kedudukan yang sangat penting bagi pengembangan segenap potensi peserta didik. la menjadi orang yang paling menentukan dalam perancangan dan penyiapan proses pendidikan dan pembelajaran. Sebagaimana yang tercantum dalam Peraturan Pemerintah Republik Indonesia Nomor 19 Tahun 2005 Pasal 19 ayat (1) tentang Standar Pendidikan Nasional sebagai berikut : Bahwa Proses pembelajaran pada satuan pendidikan diselenggarakan secara interaktif, inspiratif, menyenangkan, menantang, memotivasi peserta didik untuk berpartisipasi aktif, serta memberikan ruang yang cukup bagi prakarsa, kreativitas, dan kemandirian sesuai dengan bakat, minat, dan perkembangan fisik serta psikologis peserta didik.

Pada kegiatan proses belajar mengajar seorang guru memiliki peranan dan posisi yang sangat strategis, guru harus mampu merencanakan dan mengembangkan kegiatan pengajaran yang menarik, kreatif dan dinamis sehingga proses belajar mengajar di dalam kelas menyenangkan bagi peserta didik.

Apalagi pada masa pandemi seperti sekarang ini, guru dan siswa memiliki keterbatasan waktu dalam kegiatan pembelajaran. Guru harus berpikir keras bagaimana cara memberikan pembelajaran yang bisa diterima siswa baik di sekolah maupun dari rumah. Model pembelajaran apa yang dapat memberikan hasil belajar yang baik dan bagaimana cara menyampaikan pembelajaran kepada siswa.

Perubahan gaya belajar ini diharapkan mampu menghasilkan kualitas pembelajaran yang optimal sesuai dengan indikator pencapaian kompetensi.Berdasarkan hal tersebut inovasi penggunaan model pembelajaran dan media pembelajaran dilakukan pada semua pembelajaran yang diajarkan tidak terkecuali pada pembelajaran tematik khususnya pada sub tema hidup bersih sehat di rumah.

Namun pada kenyataannya masih ditemukan permasalahan tentang rendahnya hasil belajar siswa. Hal tersebut dapat diketahui melalui hasil ulangan yang masih di bawah KKM. Dari 13 siswa hanya 5 siswa (38\%) yang mendapat nilai diatas 70. Sisanya sebanyak 8 (62\%) anak mendapat nilai di bawah 70 . Adapun nilai tertinggi yaitu 82 dan nilai terendah 50, dengan nilai rata-rata kelas 63 .

Permasalahan tersebut perlu diatasi karena dapat berpengaruh pada prestasi belajar siswa. Menanggapi permasalahan tersebut, peneliti berupaya mencari solusi untuk meningkatkan hasil belajar siswa kelas 2 SD Negeri 2 Sered dengan menggunakan model pembelajaran problem based learning dengan media pembelajaran power point.

\section{METODE}

Bagian ini disajikan jika artikel merupakan hasil penelitian (hasil kajian tidak perlu menyajikan bagian ini). Bagian ini disajikan maksimal 200 kata. Bagian ini dipaparkan 
jenis penelitian, data dan sumber data, teknik dan alat pengumpulan data, serta teknik analisi data yang digunakanPenelitian ini adalah penelitian tindakan kelas (Classroom Action Research) dengan menerapkan model pembelajaran Problem Based Learning (PBL). Menurut Kurt Lewin dalam Kunandar (2011: 42) penelitian tindakan kelas ini terdiri dari empat tahapan dasar yaitu perencanaan (planning), pelaksanaan (acting), pengamatan (observing) dan refleksi (reflecting). Analisis penelitian ini adalah analisis deskriptif kuantitafif kualitatif dimana dalam penelitian ini selain penyajian hasil berupa data maupun angka peneliti juga menentukan bagaimana cara pengolahan hasil penelitian yakni dengan membuat analisisnya dengan menerapkan model penelitian Problem Based Learning (PBL). Penelitian ini dilaksanakan pada peserta didik kelas II SD Negeri 2 Sered Tahun Pelajaran 2020/2021 selama dua siklus dengan satu pertemuan disetiap siklusnya. Siklus I dilaksanakan pada tanggal 16 November 2020. Siklus II dilaksanakan pada tanggal 23 November 2020. Teknik pengumpulan data yang dilakukan dengan observasi dan tes.

\section{HASIL DAN PEMBAHASAN}

Pada siklus I pembelajaran dilaksanakan selama satu pertemuan, setiap pertemuan diadakan pre test dan post test. Untuk mengetahui perkembangan peserta didik selama pembelajaran. Siklus I membahas materi bentuk pola irama, amanat dan kosakata dan bangun datar. Pembelajaran dengan model Problem Based learning dilaksanakan dengan 6 langkah secara berurutan mulai dari Orientasi masalah, Keorganisasan peserta didik, Pebimbingan investigasi peserta didik, Penyajian hasil diskusi, Analisis dan evaluasi proses mengatasi masalah. Berikut ini adalah hasil belajar peserta didik pada siklus I yang bisa dilihat pada tabel berikut.

Tabel 1. Hasil Peserta didik Siklus I

\begin{tabular}{cccccccccc}
\hline & \multicolumn{3}{c}{ Pre test } & \multicolumn{3}{c}{ Post test } \\
\cline { 2 - 9 } Siklus 1 & $\begin{array}{l}\text { Pesdik } \\
\text { tuntas }\end{array}$ & $\begin{array}{l}\text { Pesdik } \\
\text { belum } \\
\text { tuntas }\end{array}$ & $\begin{array}{l}\text { Pesdik } \\
\text { tuntas }\end{array}$ & $\begin{array}{l}\text { Pesdik } \\
\text { belum } \\
\text { tuntas }\end{array}$ \\
\cline { 2 - 9 } & $\mathrm{Jml}$ & $\%$ & $\mathrm{Jml}$ & $\%$ & $\mathrm{Jml}$ & $\%$ & $\mathrm{Jml}$ & $\%$ \\
\hline Pertemuan 1 & 5 & 38 & 8 & 62 & 8 & 62 & 5 & 38 \\
\hline
\end{tabular}

Berdasarkan tabel di atas maka terjadi peningkatan antara pre test dan post test pada pertemuan 1. Setiap individu peserta didik sudah mengalami peningkatan hasil belajarnya. Peserta didik mengalami peningkatan hasil belajar pada pertemuan 1. Ketuntasan klasikal juga mengalami peningkatan, pada pre test hanya terdapat 5 anak yang sudah tuntas, tetapi pada post test bertambah menjadi 8 anak yang sudah tuntas dengan Kriteria Ketuntasan Minimal (KKM) sebesar 70. Pada pertemuan 1 peserta didik yang sudah tuntas hanya ada 7 anak, Persentase ketuntasan klasikalnya meningkat, pada pertemuan 1 siklus I sebesar $62 \%$. Berdasarkan refleksi pada siklus I maka diputuskan untuk melanjutkan ke siklus II dikarenakan belum mencapai ketuntasan klasikal yang diharapkan. Siklus II membahas materi persatuan dalam keberagaman di rumah dan kosakata lingkungan sehat dan tidak sehat.

Pembelajaran dengan model Discovery learning dilaksanakan dengan 6 langkah secara berurutan seperti siklus I. Berikut ini adalah hasil belajar peserta didik pada siklus II yang bisa dilihat pada tabel berikut

Tabel 1. Hasil Peserta didik Siklus II 


\begin{tabular}{c|cccccccc}
\hline & \multicolumn{3}{c}{ Pre test } & \multicolumn{4}{c}{ Post test } \\
Siklus 1 & $\begin{array}{c}\text { Pesdik } \\
\text { tuntas }\end{array}$ & $\begin{array}{c}\text { Pesdik } \\
\text { belum tuntas }\end{array}$ & \multicolumn{2}{c}{$\begin{array}{c}\text { Pesdik } \\
\text { tuntas }\end{array}$} & \multicolumn{2}{c}{$\begin{array}{c}\text { Pesdik } \\
\text { belm } \\
\text { tuntas }\end{array}$} \\
& Jml & $\%$ & $\mathrm{Jml}$ & $\%$ & $\mathrm{Jml}$ & $\%$ & $\mathrm{Jml}$ & $\%$ \\
\hline $\begin{array}{c}\text { Pertem } \\
\text { uan 1 }\end{array}$ & 8 & 62 & 5 & 38 & 11 & 85 & 2 & 15 \\
\hline
\end{tabular}

Berdasarkan tabel di atas maka terjadi peningkatan antara pre test dan post test pada pertemuan 1. Setiap individu peserta didik sudah mengalami peningkatan hasil belajarnya. Ketuntasan klasikal juga mengalami peningkatan, pada pre test hanya terdapat 8 anak yang sudah tuntas, tetapi pada post test bertambah menjadi 11 anak yang sudah tuntas dengan Kriteria Ketuntasan Minimal (KKM) sebesar 70. Pada pertemuan 1 siklus II peserta didik yang sudah tuntas ada 11 anak, Persentase ketuntasan klasikalnya meningkat, yaitu $85 \%$ Dari dua siklus yang sudah dilaksanakan selama 2 pertemuan dapat dipastikan bahwa model pembelajaran Problem Based learning berbantuan media power point dapat meningkatkan hasil belajar peserta didik pada tema 4 hidup bersih dan sehat Kelas II di SD Negeri 2 Sered.

\section{SIMPULAN}

Penerapan model pembelajaran Problem Based Learning (PBL) dapat meningkatkan hasil belajar tematik tema 4 hidup bersih dan sehat pada kelas II SD Negeri 2 Sered. Peningkatan yang terjadi karena adanya kesan pembelajaran yang mendalam dari peserta didik tehadap materi yang diajarkan melalui setiap sintak yang dilalui. Peserta didik akan selalu teringat akan materi yang diajarkan dikarenakan mereka dapat mengembangkan ketrampilan berfikir dan ketrampilan pemecahan masalah. Berdasarkan penelitian yang telah dilaksanakan salah satu model pembelajaran yang harus dikuasai guru adalah Problem Based learning karena model ini sangat cocok digunakan dalam keadaan pandemi seperti ini, apalagi dalam kondisi belajar dari rumah. Peserta didik akan menyusun pengetahuannya sendiri, menumbuh kembangkan ketrampilan yang lebih tinggi dan inquiri, memandirikan siswa dan meningkatkan kepercayaan diri sendiri dengan media powerpoint.

\section{DAFTAR PUSTAKA}

Bahtraedu. 2015.Media Pembelajaran Power Point.wordpres.com.2 Mei 2015. Jam 13.40

Dhelilik.2019.sintaks model problem based learning dalam pembelajaran. Bertema.com,11 Agustus 2019 jam13.00

Kementerian Pendidikan dan Kebudayaan. (2017). Buku guru edisi revisi 2018:

Kementerian Pendidikan dan Kebudayaan. (2017). Buku siswa edisi revisi 2018:

Rusman (2010).Model-model pembelajaran (Mengembangkan Profesionalisme Guru Edisi Kedua). Jakarta: Raja Grafindo Persada

Rusman. 2011. Model-Model Pembelajaran Mengembangkan Profesionalisme Guru. Jakarta: Rajawali Pers

Rusman. 2012. Model-Model Pembelajaran: Mengembangkan Profesionalisme Guru. Jakarta: Raja Grafindo Persada 